\title{
Retirement Need Analysis: How Much of My Current Income Will I Need for Retirement?'
}

\author{
Jorge Ruiz-Menjivar and Martie Gillen²
}

\section{Introduction}

A common question when planning for retirement is "How much money will I need during that stage of life?" The answer varies by individual and that person's objectives. Several factors play an important role in answering this question. One main factor is the desired standard of living. In general, most people entering into retirement intend to maintain the same preretirement lifestyle. Lifestyle changes could decrease or increase income needs once an individual retires. Additional spending such as entertainment, eating out, travel, vacation, and other changes might increase expenses. However, these lifestyle expenses are discretionary and can be adjusted to fit a person's budget.

Another factor to consider is that expenses related to employment (e.g., clothing costs, meal costs, parking, gas, etc.) and payroll taxes (e.g., FICA-federal payroll tax) generally decrease during retirement years. On the other hand, some personal expenses such as health-related expenses may increase. Table 1 provides a list of general elements that impact expenses during retirement years.

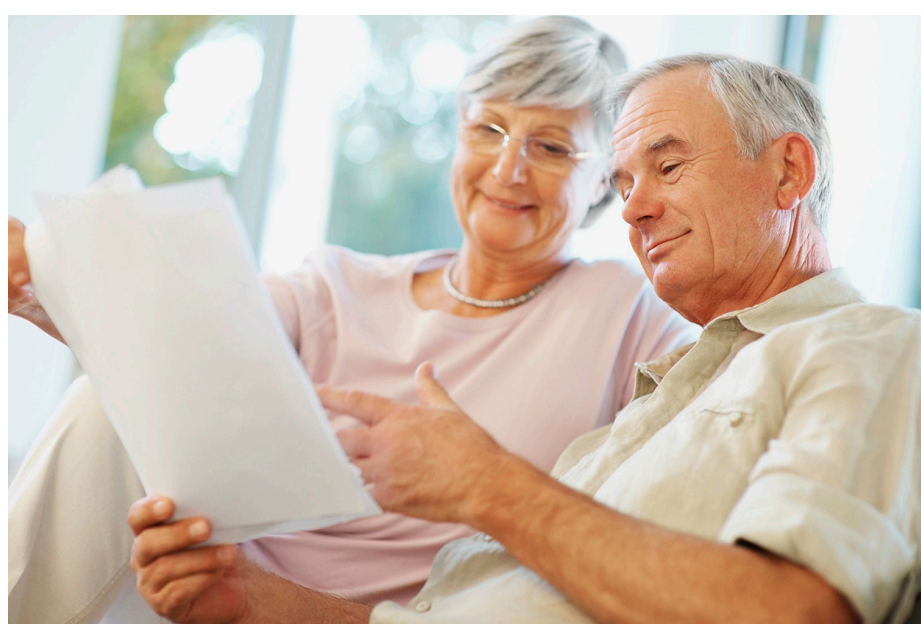

Figure 1. The amount of money needed for retirement varies from person to person. There may not be an exact amount, but there are ways to estimate the amount you will need. Credits: iStockphoto

Table 1. Factors that impact expenses during retirement.

\begin{tabular}{|l|l|}
\hline $\begin{array}{l}\text { Factors that might decrease } \\
\text { your income needs }\end{array}$ & $\begin{array}{l}\text { Factors that might increase your } \\
\text { income needs }\end{array}$ \\
\hline Social Security payments & Health-related costs \\
\hline $\begin{array}{l}\text { Expenses associated } \\
\text { with employment (e.g., } \\
\text { transportation, clothing, etc.) }\end{array}$ & $\begin{array}{l}\text { Lifestyle adjustment (e.g., more } \\
\text { travel, } \\
\text { hobbies, clubs, or other activities) }\end{array}$ \\
\hline Automobile insurance & Home maintenance and repair \\
\hline Lifestyle changes & \\
\hline
\end{tabular}

1. This document is FCS7251, one of a series of the Department of Family, Youth and Community Sciences, Florida Cooperative Extension Service, Institute of Food and Agricultural Sciences, University of Florida. First published March 2013. Please visit the EDIS website at http://edis.ifas.ufl.edu.

2. Jorge Ruiz-Menjivar, graduate student; and Martie Gillen, assistant professor, Department of Family, Youth and Community Sciences; Florida Cooperative Extension Service, Institute of Food and Agricultural Sciences, University of Florida, Gainesville, FL 32611. 


\section{Wage Replacement Ratio}

There is not a single "magic number" that guarantees an adequate retirement. But many indicators and methods can help estimate and determine a reasonable amount appropriate for your needs during retirement. One of these indicators is the wage replacement ratio (WRR).

The wage replacement ratio indicates the percentage of current annual income that an individual will need during retirement to maintain the same preretirement lifestyle. On average, many financial planners report that clients need approximately $70 \%-80 \%$ of their preretirement income to retire and maintain the same lifestyle (Dalton 2008).

Experts recommend that a replacement wage ratio of $70 \%-80 \%$ is appropriate at the beginning of the retirement stage. Studies suggest that consumption usually declines as people get older. More precisely, results indicate that after age 80 , there is an evident reduction in consumption; however, be aware that some other expenses might rise during the latter part of retirement (e.g., medical costs).

Two different approaches used to calculate this helpful indicator (WRR) are the top-down and bottom-up. Below, each approach is explained, and examples are provided to illustrate their application. However, in practice, calculations can be more detailed if additional factors are considered (e.g., inflation, rate of return on investment, Social Security benefits, etc.).

\section{Top-Down Approach}

This method is very intuitive and uses known percentages of your current financial situation to estimate the wage replacement ratio (WRR). Often, this approach is used with individuals whose income and expenditure trends are expected to vary over time. For example, younger individuals will likely experience more changes in income and expense patterns than those near retirement age.

As an example of this approach, let's assume Michael is 32 years old and earns $\$ 35,000$ a year before taxes. He pays $7.65 \%$ of his gross income in payroll taxes (FICA, Social Security, and Medicare). Also, Michael annually saves 5\% of his gross income and puts another 3\% in his retirement plan as a minimum requirement from his employer (this will vary by employer). Thus, the WRR is $84.35 \%$, meaning that during retirement he would need approximately $\$ 29,522.50$ per year to maintain his current lifestyle. Table 2 shows the step-by-step calculation of WRR under this method.
Table 2. Sample wage replacement ratio (WRR) calculation using the top-down approach.

\begin{tabular}{|l|c|c|}
\hline & Dollar amount & Percentage \\
\hline Salary & 35,000 & $100 \%$ \\
\hline $\begin{array}{l}\text { Less: Payroll taxes } \\
(35,000 * 7.65 / 100)\end{array}$ & $(2,677.50)$ & $(7.65 \%)$ \\
\hline $\begin{array}{l}\text { Less: Current savings } \\
(35,000 * 5 / 100)\end{array}$ & $(1,750)$ & $(5 \%)$ \\
\hline $\begin{array}{l}\text { Less: Required contribution } \\
\text { to retirement plan } \\
\text { (35,000*3/100) }\end{array}$ & $(1,050)$ & $(3 \%)$ \\
\hline Wage Replacement Ratio & $\mathbf{\$ 2 9 , 5 2 2 . 5 0}$ & $\mathbf{8 4 . 3 5 \%}$ \\
\hline
\end{tabular}

\section{Bottom-Up Approach}

The bottom-up approach is a more comprehensive method to calculate the wage replacement ratio (WRR). It takes into consideration a more detailed list of current expenditures, enabling a more accurate estimate of future expenditure patterns and retirement needs. This approach is often used with individuals closer to retirement (usually these individuals' expenditures and income are less subject to changes). Because the bottom-up approach considers the main elements of a budget, this method is also known as a budgeting approach.

To illustrate this approach, consider the following example. Wendy, age 54, has the current income and expenses listed in Table 3. Her retirement objectives are to have no mortgage payment during retirement and to maintain her current lifestyle. As previously discussed, some expenses, such as consumption of goods and work-related expenses, are expected to decline during retirement years. Those estimated declines are reflected in Wendy's retirement budget shown in Table 3.

By using the bottom-up (budgeting) approach, the WRR for Wendy is $58.18 \%$. In other words, during retirement years, she would need $58.18 \%$ of her current income to maintain her current lifestyle; that is a total of $\$ 37,820$. Note that neither preretirement nor postretirement inflation is considered in this calculation. 
Table 3. Sample wage replacement ratio (WRR) calculation using the bottom-up approach.

\begin{tabular}{|c|c|c|}
\hline & Current budget & $\begin{array}{c}\text { Retirement } \\
\text { budget }\end{array}$ \\
\hline Current Income & $\$ 65,000$ & 0 \\
\hline \multicolumn{3}{|l|}{ Expenses } \\
\hline Income taxes* & 11,000 & 11,000 \\
\hline Social Security taxes & 4,875 & 0 \\
\hline Mortgage & 10,800 & 0 \\
\hline Homeowner's insurance & 2,760 & 2,760 \\
\hline Health insurance & 540 & 540 \\
\hline Car payment & 3,000 & 3,000 \\
\hline Auto insurance & 780 & 780 \\
\hline Auto maintenance & 1,000 & 700 \\
\hline Food & 6,000 & 6,000 \\
\hline Utilities & 4,200 & 4,200 \\
\hline Clothing & 3,655 & 2,000 \\
\hline Gas & 1,200 & 840 \\
\hline Savings & 9,190 & 0 \\
\hline Entertainment & 3,000 & 3,000 \\
\hline Miscellaneous & 3,000 & 3,000 \\
\hline Total expenses (needs) & $\$ 65,000$ & $\$ 37,820$ \\
\hline $\begin{array}{l}\text { Wage Replacement Ratio } \\
\text { (Total expenses/ } \\
\text { income)*100 }\end{array}$ & & $58.18 \%$ \\
\hline
\end{tabular}

\section{Summary}

While no "magic number" exists for the amount you should save for retirement, there are calculations you can use to estimate the amount you will need. Calculating your wage replacement ratio (WRR) using either the top-down or bottom-up approach can help you determine how much money you should put aside for retirement and provide you with savings goals.

For more information on retirement financial planning, see other EDIS publications at http://edis.ifas.ufl.edu/ topic_retirement.

\section{Reference}

Dalton, M. 2008. Retirement Planning and Employee Benefits for Financial Planners, fifth edition. S. Rose, LA: Money Education. 